\title{
Caesalpinia pulcherrima seed galactomannan on rheological properties of dairy desserts
}

\section{Stella Regina Arcanjo Medeiros ${ }^{1^{*}}$ (D) Victor Alves de Oliveira ${ }^{1}$ Amanda Mazza Cruz de Oliveira ${ }^{2}$ Marjory Lima Holanda Araujo ${ }^{3}$ Judith Pessoa de Andrade Feitosa ${ }^{4}$ Regina Celia Monteiro de Paula ${ }^{4}$ Felipe Domingos de Sousa ${ }^{5}$ Ana Cristina de Oliveira Monteiro Moreira ${ }^{5}$ Frederico José Beserra $^{5}$ Renato de Azevedo Moreira ${ }^{5}$}

${ }^{1}$ Curso de Bacharelado em Nutrição, Universidade Federal do Piauí (UFPI), 64607-670, Picos, PI, Brasil. E-mail: stellaarcanjo@ufpi.edu.br. ${ }^{*}$ Corresponding author.

${ }^{2}$ Instituto Federal de Educação, Ciência e Tecnologia do Ceará, Campus Sobral, Sobral, CE, Brasil.

${ }^{3}$ Departamento de Bioquímica e Biologia Molecular, Universidade Federal do Ceará (UFC), Fortaleza, CE, Brasil.

${ }^{4}$ Departamento de Química Orgânica e Inorgânica, Universidade Federal do Ceará (UFC), Fortaleza, CE, Brasil.

${ }_{5}^{5}$ Núcleo de Biologia Experimental (NUBEX), Universidade de Fortaleza (UNIFOR), Fortaleza, CE, Brasil.

ABSTRACT: Dairy desserts containing Caesalpinia pulcherrima seed galactomannan were evaluated to determine their static and dynamic rheological behaviors. Variations in consistency index $(k)$, flow behavior $(n)$, yield stress and thixotropy of the desserts indicated that the galactomannan caused an increase in the shear stress and apparent viscosity of the system. All samples exhibited shear-thinning behavior with flow behavior index values (n) between 0.06 and 0.37. Dynamic rheological behavior was evaluated for MD (high solid levels) and MD/2 (half the amount of solids) groups, and both $G$ ' and $G$ " moduli were depended on the frequency. The MD and MD/2 groups showed variations in the elastic modulus $\left(G\right.$ ') throughout the temperature range (mainly at $50^{\circ} \mathrm{C}$ ), showing greater sensitivity at high temperatures. C. pulcherrima galactomannan was able to promote synergism with starch, milk protein and sucrose and to improve the development of stronger and more resistant gels.

Key words: pseudoplastic, thickener, synergism, viscosity, temperature.

Efeito da galactomanana da semente de Caesalpinia pulcherrima sobre as propriedades reológicas de sobremesas lácteas

RESUMO: Sobremesas lácteas contendo galactomanana de semente de Caesalpinia pulcherrima tiveram suas propriedades reológicas estáticas e dinâmicas avaliadas. As variações nos índices de consistência (K) e comportamento de fluxo (n), assim como na tensão inicial de fluxo e na tixotropia das sobremesas mostraram o efeito da galactomanana sobre a tensão de cisalhamento e viscosidade aparente dos sistemas lácteos. Todas as sobremesas exibiram comportamento pseudoplástico, com índices de comportamento de fluxo (n) variando entre 0,06 e 0,37. A reologia dinâmica dos grupos MD (alto teor de sólidos) e MD/2 (metade do teor de sólidos), mostrou $G$ '> $G$ ” e módulos dependentes da frequência e da temperatura. Alterações químicas nos componentes das sobremesas foram observadas a $50^{\circ} \mathrm{C}$ em virtude da maior sensibilidade dos valores de G'e G" a partir dessa temperatura. A galactomanana de C. pulcherrima contribuiu para o desenvolvimento de géis mais fortes e resistentes nas sobremesas lácteas, bem como mostrou sinergismo com amido, proteina do leite e sacarose.

Palavras-chave: pseudoplástico, espessante, sinergismo, viscosidade, temperatura.

\section{INTRODUCTION}

Hydrocolloids are a heterogeneous group of long chain polymers that have the specific ability to form viscous dispersions and/or gels in water. Food gums/hydrocolloids such as starch, xanthan, guar gum,
LBG, karaya, Arabic gum and cellulose derivatives display a wide range of functional properties, such as texture emulsifier and stabilizer (CEVOLI et al., 2013). Among the processed foods, the dairy desserts, which are usually composed of milk, hydrocolloids, sucrose, flavor and colorants, show shear-thinning 
flow behavior and time-dependence in addition to typical viscoelastic properties of weak gels. Perceptible differences in rheological behavior have been reported in commercial samples (TÁRREGA et al., 2003; TÁRREGA et al., 2004, 2006) and in model systems with different compositions ( $\mathrm{F}$. VÉLEZ-RUIZ et al., 2005; LETHUAUT et al., 2003; WISCHMANN et al., 2002). Hydrocolloids play an important role in the development of dairy desserts by modifying the characteristic consistency of these products. These molecules can prevent or delay the following physical phenomena: dispersed solid particle sedimentation in the medium, water or sugar crystallization, dispersed particle aggregation or disaggregation, and syneresis of gelled systems (ANTÔNIO et al., 2003).

$$
\text { Galactomanna are neutral }
$$

heteropolysaccharides composed of a $\beta-(1 \rightarrow 4)$-Dmannan backbone with single $\mathrm{D}$-galactose branches with $\alpha-(1 \rightarrow 6)$ linkage, with potential applications in the food industry. They are reported in the endospermic cell walls of various Leguminosae seeds and differ from each other in their mannose: galactose ratio, distribution pattern of galactose residues along the mannan backbone, molecular weight, and molecular weight distribution. The galactose substitution degree in galactomanano determines its physicochemical properties. The LBG (Ceratonia siliqua L.), guar (Cyamopsis tetragonoloba) and tara gums (Caesalpinia spinosa) are the three major galactomannans of commercial importance in the food industry (KAPOOR \& DIVISIONS, 2005; MIKKONEN et al., 2007; PRAJAPATI et al., 2013). Starches behave differently from galactomannans and their properties are complementary. Starches have rheological properties that are influenced by other factors in the formulations, such as water activity, ionic strength and $\mathrm{pH}$, and by processing variables such as thermal load, shear stress and filling temperatures (FINCH, 1998).

The interest in new galactomannan sources has increased in the last years. Among these sources, Caesalpinia pulcherrima belongs to the Caesalpiniaceae subfamily of Leguminosae, and its seeds accumulate large amounts of galactomannan with potential applications in the food industry as a hydrocolloid, edible coatings and fiber source (BURITI et al., 2014; CERQUEIRA, et al., 2009; WU, et al., 2015). This specie; although, native from Central America is well adapted to the Brazilian savanna.

Rheological properties are related to the textural attributes of products, which determine their sensory characteristics and consumer acceptability.
Furthermore, rheological data are often required as an indicator of product quality for the calculation of many processes involving fluid flow, such as pasteurization, evaporation, drying and aseptic processing (CEVOLI et al., 2013; MA et al., 2014).

Therefore, this research aimed to evaluate the effect of galactomannan from Caesalpinia pulcherrima seeds on the rheological properties of dairy desserts containing starch, sucrose and milk.

\section{MATERIALS AND METHODS}

\section{Materials}

Caesalpinia pulcherrima seeds were collected in the State of Ceara, Brazil. Powdered milk, corn starch and sucrose were purchased from Nestlé $^{\circledR}$, Maizena ${ }^{\circledR}$ and União ${ }^{\circledR}$, respectively, at the Fortaleza-Ceara local market.

\section{Galactomannan extraction and characterization}

The C. pulcherrima galactomannans were extracted from seed endosperm as described by (CERQUEIRA \& OTHERS, 2009). Briefly, the seeds were removed from the pods, cleaned and milled. The endosperms were manually separated from the cotyledons and the hulls, and they were then suspended in $96 \%$ ethanol in a $2: 1$ proportion (ethanol: water) and heated at $70{ }^{\circ} \mathrm{C}$ for $15 \mathrm{~min}$ to inactivate the enzymes and eliminate low molecular weight compounds. Ethanol was decanted followed by the addition of distilled water in a 1:5 proportion (endosperm: water), and the solution was incubated for $24 \mathrm{~h}$ at $8{ }^{\circ} \mathrm{C}$. Water was added to the extract at a 1:10 ratio (suspension: water), and the solution was mixed in a blender for $5 \mathrm{~min}$ and filtered through a nylon net. The obtained solution was precipitated with $96 \%$ ethanol in a 1:3 proportion (v:v). The precipitated galactomannan was dehydrated with acetone and submitted to air flow drying.

\section{Analysis of monosaccharides composition}

Galactomannan hydrolysis and monosaccharides derivatization processes were carried out as described by XU et al. (2012). Galactose and mannose contents were determined using gas chromatography with mass spectrometer detector (GCMS- QP2010, Shimadzu, Tokyo, Japan). Samples were injected in split mode (1:25), using helium as a carrier gas at a constant flow of $1.16 \mathrm{~mL} / \mathrm{min}$; the injection volume was $1 \mu \mathrm{L}$. The monosaccharides separation was performed on a RTX-5MS column $(30 \mathrm{~m} \times 0.25 \mathrm{~mm}$ i.d. $\times 0.25 \mu \mathrm{m}$ film thickness $)$ (Restec, Bellefonte, USA). The oven temperature 
was programmed to change in the following way: constant at $160{ }^{\circ} \mathrm{C}$ for $3 \mathrm{~min}$, then raised at the rate of $1{ }^{\circ} \mathrm{C} / \mathrm{min}$ to $190{ }^{\circ} \mathrm{C}$ and finally raised by $15^{\circ} \mathrm{C} / \mathrm{min}$ to $240^{\circ} \mathrm{C}$ and held for $1 \mathrm{~min}$. Each sample was run in triplicate by GC-MS.

\section{Protein content}

Nitrogen content was determined according to the method described by BAETHGEN \& ALLEY (1989) and related to the total protein content by a factor of N x 5.87 (AZERO \& ANDRADE, 2002).

\section{Molar mass distribution}

Evaluation of the weight average molar mass $(\mathrm{Mw})$ and number average molar mass $(\mathrm{Mn})$ were performed using gel permeation chromatography (GPC) with a Shimadzu LC-10AD instrument using an Ultrahydrogel linear column $(7.8 \times 300 \mathrm{~mm})$. An aqueous solution of polysaccharides $(0.1 \%, \mathrm{w} / \mathrm{v})$ was injected at a flow rate of $0.5 \mathrm{~mL} / \mathrm{min}$, and 0.1 $\mathrm{M} \mathrm{NaNO}_{3}$ was the eluent. A differential refractometer was used as the detector at $40{ }^{\circ} \mathrm{C}$. Pullulan samples (Shodex Denko) with Mw values of $5.9 \times 10^{3}$, $1.18 \times 10^{4}, 4.73 \times 10^{4}, 2.12 \times 10^{5}$, and $7.88 \times 10^{5}$ $\mathrm{g} \mathrm{mol}^{-1}$ were used as molecular standards. The weight average molar mass and number average molar mass $(\mathrm{Mn})$ were estimated via comparison to pullulan standard curves.

\section{Viscometric measurements \\ Viscometric measurements were performed at $26 \pm 0.1{ }^{\circ} \mathrm{C}$ using an Ostwald Fensk}

capillary viscometer $\left(\mathrm{n}^{\circ} 200\right)$. Specific concentrations of the galactomannan solutions were established such that the relative viscosity values were between 1.2 and 2.0, which were considered adequate for maintaining these solutions within the Newtonian plateau. Huggins-Kramer plots of $\eta_{\mathrm{sp}} / \mathrm{C}$ and $\ln \eta_{\mathrm{r}} / \mathrm{C}$ versus $\mathrm{C}$ were used to estimate intrinsic viscosity [ $\eta]$ according to equations 1 and 2:

$$
\begin{aligned}
& {\left[\mathrm{n}_{s p}\right]=[\mathrm{n}]+\mathrm{k}_{\mathrm{H}}[\mathrm{\eta}]^{2} C} \\
& \frac{\ln \eta_{r}}{c}=[\eta]+k_{k}[\eta]^{2} C
\end{aligned}
$$

where $\eta_{\mathrm{sp}}$ is the specific viscosity; $\eta_{\mathrm{r}}$ is the relative viscosity; $[\eta]$ is the intrinsic viscosity; $C$ is the polymer concentration; $k_{\mathrm{H}}$ is Huggins' constant; and $k_{\mathrm{K}}$ is Kramer's constant.

\section{Dairy dessert preparation}

Dairy desserts were distributed into two groups (MD: high solid levels and MD/2: half the amount of solids) containing galactomannan $(\mathrm{G})$, corn starch (S), sucrose $(\mathrm{Sg})$ and powdered milk $(\mathrm{M})$, in order to evaluate the influence of each one on the rheological behavior of the dairy desserts (Table 1). A total of ten formulations were evaluated in triplicate for the tests proposed. The MD group was prepared with a base formulation and $\mathrm{MD} / 2$ group consisted of a dairy dessert made with subtraction of half the concentration of each ingredient. In these groups $C$. pulcherrima galactomannan $(0.5$ and $1.7 \%, \mathrm{w} / \mathrm{v}$ ) were added to powdered milk, sucrose and corn starch, and these solutions were stirred at $80{ }^{\circ} \mathrm{C}$ for $20 \mathrm{~min}$ in order to promote a better dissolution of the materials and pasteurization of dairy desserts.

\begin{tabular}{|c|c|c|c|c|c|}
\hline \multirow[t]{2}{*}{ Dairy dessert group } & \multirow[t]{2}{*}{ Sample code } & \multicolumn{3}{|c|}{ 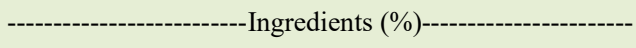 } & \multirow[t]{2}{*}{ Galactomannan } \\
\hline & & Powderedmilk & Sucrose & Corn starch & \\
\hline & MD & 16.37 & 13.37 & 3.35 & 1.7 \\
\hline & MD - G & 16.37 & 13.37 & 3.35 & 0.5 \\
\hline \multirow[t]{5}{*}{ MD } & MD - S & 16.37 & 13.37 & 0.65 & 1.7 \\
\hline & $\mathrm{MD}-\mathrm{Sg}$ & 16.37 & 6.63 & 3.35 & 1.7 \\
\hline & $\mathrm{MD}-\mathrm{M}$ & 9.63 & 13.37 & 3.35 & 1.7 \\
\hline & $\mathrm{MD} / 2$ & 9.63 & 6.63 & 0.65 & 0.5 \\
\hline & $\mathrm{MD} / 2+\mathrm{G}$ & 9.63 & 6.63 & 0.65 & 1.7 \\
\hline \multirow[t]{3}{*}{$\mathrm{MD} / 2$} & $\mathrm{MD} / 2+\mathrm{S}$ & 9.63 & 6.63 & 3.35 & 0.5 \\
\hline & $\mathrm{MD} / 2+\mathrm{Sg}$ & 9.63 & 13.37 & 0.65 & 0.5 \\
\hline & $\mathrm{MD} / 2+\mathrm{M}$ & 16.37 & 6.63 & 0.65 & 0.5 \\
\hline
\end{tabular}

Table 1 - Dairy desserts compositions.

MD: high solid levels; MD/2: half the amount of solids; G: galactomannan; S: corn starch; Sg: sucrose; M: powdered milk. 
Samples were cooled, distributed in packaging, and stored under refrigeration $\left(5^{\circ} \mathrm{C}\right)$ for $48 \mathrm{~h}$ before analyses.

\section{Physicochemical parameters}

The dairy desserts were subjected to physical-chemical analysis using the following AOAC methods: moisture ( ${ }^{\circ}$ 930.15), ash ( $\mathrm{n}^{\circ}$ 942.05), protein ( $\mathrm{n}^{\circ}$ 984.13) and lipids ( $\mathrm{n}^{\circ}$ 954.02). Soluble solid content was determined by direct reading in an Atago Digital Refractometer (PR-101) .The total carbohydrate content was determined by difference among total mass and moisture, ash, protein and lipids content of dairy desserts. The $\mathrm{pH}$ was determined in a digital Micronal B474 potentiometer. All the analyses were performed in triplicate.

\section{Rheological analyses}

An Advanced Rheometer (AR 550) with a Peltier control system was used to evaluate the galactomannan solutions and rheological behaviors of dairy desserts. The analyses were performed using the cone-plate methodology (cone: angle $0^{\circ} 59^{\prime} 01,40$ $\mathrm{mm}$ diameter and $28 \mu \mathrm{m}$ gap).

\section{Steady measurements}

The steady rheological properties of the MD and MD/2 dairy desserts as well as the galactomannan solutions were measured based on increasing (forward measurements) and decreasing (backward measurements) shear rates varying between 5 and $300 \mathrm{~s}^{-1}$ at $25^{\circ} \mathrm{C}$. This range included parameters from mouthfeel up to industry processes involving fluid flow. Shear stress $(\tau)$ versus shear rate $(\gamma)$ comparisons were performed to predict the flow curves, and the consistency index $(k)$, flow behavior index $(n)$, yield stress $\left(\sigma_{0}\right)$ and Casson plastic viscosity $\left(\mathrm{k}_{\mathrm{v}}\right)$ were obtained according to the power law, Herschel-Bulkley and Casson models as per equations 3,4 and 5 , respectively, as follows:

$$
\begin{aligned}
& \tau=k \cdot \gamma^{n} \\
& \tau=\tau_{0}+K \cdot \gamma^{n} \\
& \tau^{0.5}=k_{V} \cdot \gamma^{0.5}+\tau_{0}^{0.5}
\end{aligned}
$$

Treatments were performed in triplicate. Upstream $\left(\mathrm{A}_{\text {up }}\right)$ and downstream $\left(\mathrm{A}_{\text {down }}\right)$ data point curves were used to estimate hysteresis area (HA). The hysteresis area was determined by the difference between the ascending and descending areas obtained from the flew curve. The thixotropic behavior was obtained by the flew curve with increasing strain rate and the lap with decreasing strain rate (hysteresis curve) according to equation 6 using Origin 8.0 software (Origin Lab Corporation, MA, USA).

$H A=A_{\text {up }}-A_{\text {down }}$

\section{Oscillatory measurements}

A frequency sweep from 0.01 to $10 \mathrm{~Hz}$ at $25^{\circ} \mathrm{C}$ with an oscillatory stress of $1.0 \mathrm{~Pa}$ (within the linear viscoelastic region) was used to generate the mechanical spectra. Elastic (G') and viscous (G”) moduli were assessed as functions of temperature by varying the temperature from 5 to $80{ }^{\circ} \mathrm{C}$ with a frequency of $1.0 \mathrm{~Hz}$ and a tension of $1.0 \mathrm{~Pa}$ for the dairy desserts and galactomannan solutions.

\section{Statistical analysis}

Data were presented as mean \pm standard deviation (S.D) and compared by one-way analysis of variance (ANOVA) followed by Tukey test at 5\% significance level $(\mathrm{p}<0.05)$ using the SPSS software (SPSS INC. 14.0 for Windows Evaluation Version). All measurements were performed in triplicate. The data were analyzed with Origin 8.0 software (Origin Lab Corporation, MA, USA).

\section{RESULTS AND DISCUSSION}

\section{Galactomannan extraction and characterization}

The extracted galactomannan presented a white color, and its yield was $27 \% \pm 0.2$ in relation to the seed mass. The protein content in the galactomannan was $0.08 \% \pm 0.01$. Protein is a common contaminant in natural polysaccharide extraction, and an absence or low level of protein is desirable because it is related to the purity of the galactomannan and specificity of the extraction method. The mannose: galactose ratio of C. pulcherrima seeds galactomannans ranges from 2.80 to 3.65 (ANDRADE et al., 1999; BURITI et al., 2014; CERQUEIRA et al., 2009). In this research, the value was of 3.86 was for this specie.

The intrinsic viscosity of $C$. pulcherrima galactomannan $\left([\eta]=9.64 \mathrm{dLg}^{-1}\right)$ was higher than that reported by (OGY et al., 1999) for this species $\left(7.4 \mathrm{dLg}^{-1}\right)$; however, it was close to the values described by (AZERO \& ANDRADE, 2002) $\left([\eta]=11.2 \mathrm{dLg}^{-1}\right)$ and lower than the values measured for commercial galactomannans (fenugreek, $15.10 \mathrm{dLg}^{-1}$; guar, $15.80 \mathrm{dLg}^{-1}$; tara 14.55 $\mathrm{dLg}^{-1}$; and LBG, $14.20 \mathrm{dLg}^{-1}$ ) by (WU et al., 2009). Intrinsic viscosity characterizes the hydrodynamic properties of macromolecules, and the Huggins' constant described the interactions between polymer chains and the solvent(AZERO \& ANDRADE, 2002). The Huggins' constant value reported for the $C$. pulcherrima galactomannan $\left(\mathrm{k}_{\mathrm{H}}=1.08\right)$ suggested the 
existence of macromolecular associations. The Huggins' constant decreases in good solvents and increases when intermolecular interactions are increased (YANG \& ZHANG, 2009). The galactomannan solution viscosities were directly influenced by the galactose distribution pattern on the mannose backbone. Thus, the variation observed in the intrinsic viscosity values might be related to the galactose substitution degree, which is influenced by seed maturation (BENTO et al., 2013). DEA et al. (1986) reported that associations occur in regions with more than six consecutive unsubstituted mannose residues.

The Mw, Mn and polydispersity values were $1.3 \times 10^{7} \mathrm{~g} \mathrm{~mol}^{-1}, 2.4 \times 10^{6} \mathrm{~g} \mathrm{~mol}^{-1}$ and 5.63, respectively. The higher molar masses ( $\mathrm{Mw}$ and $\mathrm{Mn}$ ) and lower intrinsic viscosity confirmed strong chain interactions and/or molecular aggregation as indicated by the Huggins' coefficient.

\section{Physicochemical parameters}

The physicochemical parameters and chemical composition of the MD and MD/2 desserts are shown in table 2. The dairy dessert $\mathrm{pH}$ in the $\mathrm{MD} / 2$ group ranged from $6.3 \pm 0.01$ at $6.6 \pm 0.03$ with significative difference $(\mathrm{P}<0.05)$ and was slightly more acidic than the MD group, which ranged from $6.7 \pm 0.02$ at $6.8 \pm 0.10$ and not presented significative difference $(\mathrm{P}<0.05)$ among dairy desserts. The dry solid contents for the MD dairy desserts was highest than MD/2 dairy desserts and ranged from $26.9 \pm 0.07$ (MD-Sg) to 33.7 $\pm 0.01 \%$. Already the $\mathrm{MD} / 2$ group shown range from $17.0 \pm 0.10(\mathrm{MD} / 2)$ to $23.5 \pm 0.10 \%(\mathrm{MD} / 2+\mathrm{M})$. There was significative difference $(\mathrm{P}<0.05)$ among the dairy desserts in the both groups. Between the MD group samples, the lowest values of protein $(2.6 \pm 0.3 \%)$, lipids $(2.6 \pm 0.08 \%)$ and ash $(0.6 \pm 0.03 \%)$ were observed in the MD-M desserts, which contained half the amount of milk. Regarding group MD / 2, the MD / 2, MD/2 $+\mathrm{S}$ and $\mathrm{MD} / 2+\mathrm{Sg}$ dairy desserts had the lowest values for protein $(2.5 \pm 0.3 \%)$, lipid content $(2.6 \pm$ $0.06 \%)$ and ash $(0.6 \pm 0.03 \%)$, whereas the higher values for protein, lipid and ash were observed for the $\mathrm{MD} / 2+\mathrm{M}$ dessert $(4.2 \pm 0.3,4.4 \pm 0.05$ and $1.02 \pm$ $0.04 \%$, respectively). The lipid content ranged between $2.6 \pm 0.05$ and $4.4 \pm 0.05 \%$ in the $\mathrm{MD}$ and $\mathrm{MD} / 2$ dairy dessert groups. The milk was the ingredient that more affected the chemical composition of the dairy desserts in both groups, presenting significative difference $(\mathrm{P}<0.05)$ to $\mathrm{MD}-\mathrm{M}$ and $\mathrm{MD} / 2+\mathrm{M}$.

\section{Steady measurements}

The galactomannan solution and dairy dessert (MD and $\mathrm{MD} / 2$ ) rheograms are shown in figure 1. The apparent viscosities of both galactomannan solutions and dairy desserts decreased with increasing shear rates at $25^{\circ} \mathrm{C}$, which was characterized as a shearthinning behavior. The 0.5 and $1.7 \%$ galactomannan solutions presented apparent viscosities of 0.32 and 15.5 Pa.s, respectively, at a shear rate of $10 \mathrm{~s}^{-1}$. The MD and MD/2 dairy dessert had viscosities of 45.5 and 0.27 $\mathrm{Pa}$, respectively. However, when the galactomannan concentration was increased in 2.8-fold in MD/2 (Figure $1 \mathrm{C})$, the apparent viscosity increased 54.8 -fold $(\mathrm{MD} / 2+\mathrm{G}$ $=14.8 \mathrm{~Pa} . \mathrm{s})$, at a shear rate of $10 \mathrm{~s}-1$, and was higher than $\mathrm{MD} / 2+\mathrm{S}(1.9 \mathrm{~Pa} . \mathrm{s}), \mathrm{MD} / 2+\mathrm{Sg}(0.3 \mathrm{~Pa} . \mathrm{s})$ and $\mathrm{MD} / 2+\mathrm{M}$ (0.6 Pa.s). Therefore, results showed that

Table 2 - Physicochemical parameters of MD and MD/2 dairy desserts.

\begin{tabular}{|c|c|c|c|c|c|c|c|}
\hline \multirow[t]{2}{*}{ Dairy desserts } & \multirow[t]{2}{*}{$\mathrm{pH}$} & \multirow[t]{2}{*}{ Dry solid (\%) } & \multicolumn{5}{|c|}{ 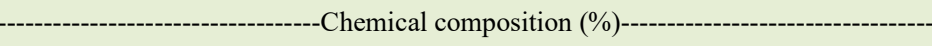 } \\
\hline & & & Moisture & Protein & Lipids & Ash & Carbohydrate \\
\hline MD & $6.8^{\mathrm{a}} \pm 0.10$ & $33.7^{\mathrm{a}} \pm 0.01$ & $66.3^{e} \pm 0.05$ & $4.3^{\mathrm{a}} \pm 0.3$ & $4.4^{\mathrm{a}} \pm 0.05$ & $1.0^{\mathrm{a}} \pm 0.01$ & $24.0^{\mathrm{a}} \pm 0.03$ \\
\hline $\mathrm{MD}-\mathrm{G}$ & $6.7^{\mathrm{a}} \pm 0.02$ & $33.2^{\mathrm{b}} \pm 0.07$ & $66.8^{\mathrm{d}} \pm 0.02$ & $4.3^{\mathrm{a}} \pm 0.2$ & $4.4^{a} \pm 0.05$ & $1.0^{\mathrm{a}} \pm 0.01$ & $23.5^{\mathrm{b}} \pm 0.03$ \\
\hline$M D-S$ & $6.7^{\mathrm{a}} \pm 0.04$ & $31.4^{c} \pm 0.08$ & $68.6^{c} \pm 0.04$ & $4.3^{\mathrm{a}} \pm 0.2$ & $4.4^{\mathrm{a}} \pm 0.07$ & $1.0^{\mathrm{a}} \pm 0.02$ & $21.7^{\mathrm{c}} \pm 0.06$ \\
\hline $\mathrm{MD}-\mathrm{Sg}$ & $6.7^{\mathrm{a}} \pm 0.06$ & $26.9^{\mathrm{e}} \pm 0.07$ & $73.1^{\mathrm{a}} \pm 0.05$ & $4.3^{\mathrm{a}} \pm 0.1$ & $4.4^{\mathrm{a}} \pm 0.08$ & $1.0^{\mathrm{a}} \pm 0.04$ & $17.2^{\mathrm{e}} \pm 0.08$ \\
\hline $\mathrm{MD}-\mathrm{M}$ & $6.7^{\mathrm{a}} \pm 0.09$ & $27.3^{\mathrm{d}} \pm 0.10$ & $72.7^{b} \pm 0.02$ & $2.6^{\mathrm{b}} \pm 0.3$ & $2.6^{\mathrm{b}} \pm 0.08$ & $0.6^{\mathrm{b}} \pm 0.03$ & $21.5^{\mathrm{d}} \pm 0.04$ \\
\hline $\mathrm{MD} / 2$ & $6.3^{\mathrm{a}} \pm 0.01$ & $17.0^{\mathrm{e}} \pm 0.10$ & $83.0^{\mathrm{a}} \pm 0.03$ & $2.5^{\mathrm{b}} \pm 0.3$ & $2.6^{\mathrm{b}} \pm 0.06$ & $0.60^{\mathrm{b}} \pm 0.03$ & $11.3^{\mathrm{e}} \pm 0.03$ \\
\hline $\mathrm{MD} / 2+\mathrm{G}$ & $6.4^{\mathrm{ac}} \pm 0.07$ & $18.3^{\mathrm{d}} \pm 0.07$ & $81.7^{b} \pm 0.03$ & $2.6^{b} \pm 0.2$ & $2.6^{\mathrm{b}} \pm 0.05$ & $0.60^{b} \pm 0.02$ & $12.5^{\mathrm{d}} \pm 0.01$ \\
\hline $\mathrm{MD} / 2+\mathrm{S}$ & $6.5^{\mathrm{bc}} \pm 0.11$ & $19.3^{\mathrm{c}} \pm 0.05$ & $80.7^{\mathrm{c}} \pm 0.04$ & $2.5^{\mathrm{b}} \pm 0.1$ & $2.6^{\mathrm{b}} \pm 0.07$ & $0.60^{b} \pm 0.03$ & $13.6^{\mathrm{c}} \pm 0.03$ \\
\hline $\mathrm{MD} / 2+\mathrm{Sg}$ & $6.5^{\mathrm{bc}} \pm 0,03$ & $23.1^{\mathrm{b}} \pm 0.06$ & $76.4^{\mathrm{d}} \pm 0.01$ & $2.5^{\mathrm{b}} \pm 0.1$ & $2.6^{\mathrm{b}} \pm 0.06$ & $0.60^{\mathrm{b}} \pm 0.04$ & $17.9^{\mathrm{a}} \pm 0.04$ \\
\hline $\mathrm{MD} / 2+\mathrm{M}$ & $6.6^{\mathrm{b}} \pm 0.03$ & $23.5^{\mathrm{a}} \pm 0.10$ & $76.4^{\mathrm{d}} \pm 0.05$ & $4.2^{\mathrm{a}} \pm 0.3$ & $4.4^{\mathrm{a}} \pm 0.05$ & $1.02^{\mathrm{a}} \pm 0.04$ & $13.8^{\mathrm{b}} \pm 0.01$ \\
\hline
\end{tabular}

MD: high solid levels; MD/2: half the amount of solids; G: galactomannan; S: corn starch; Sg: sucrose; M: powdered milk. Means \pm standard deviation. Different letters in the same line differed from each other by the Tukey test $(\mathrm{P}<0.05)$. 


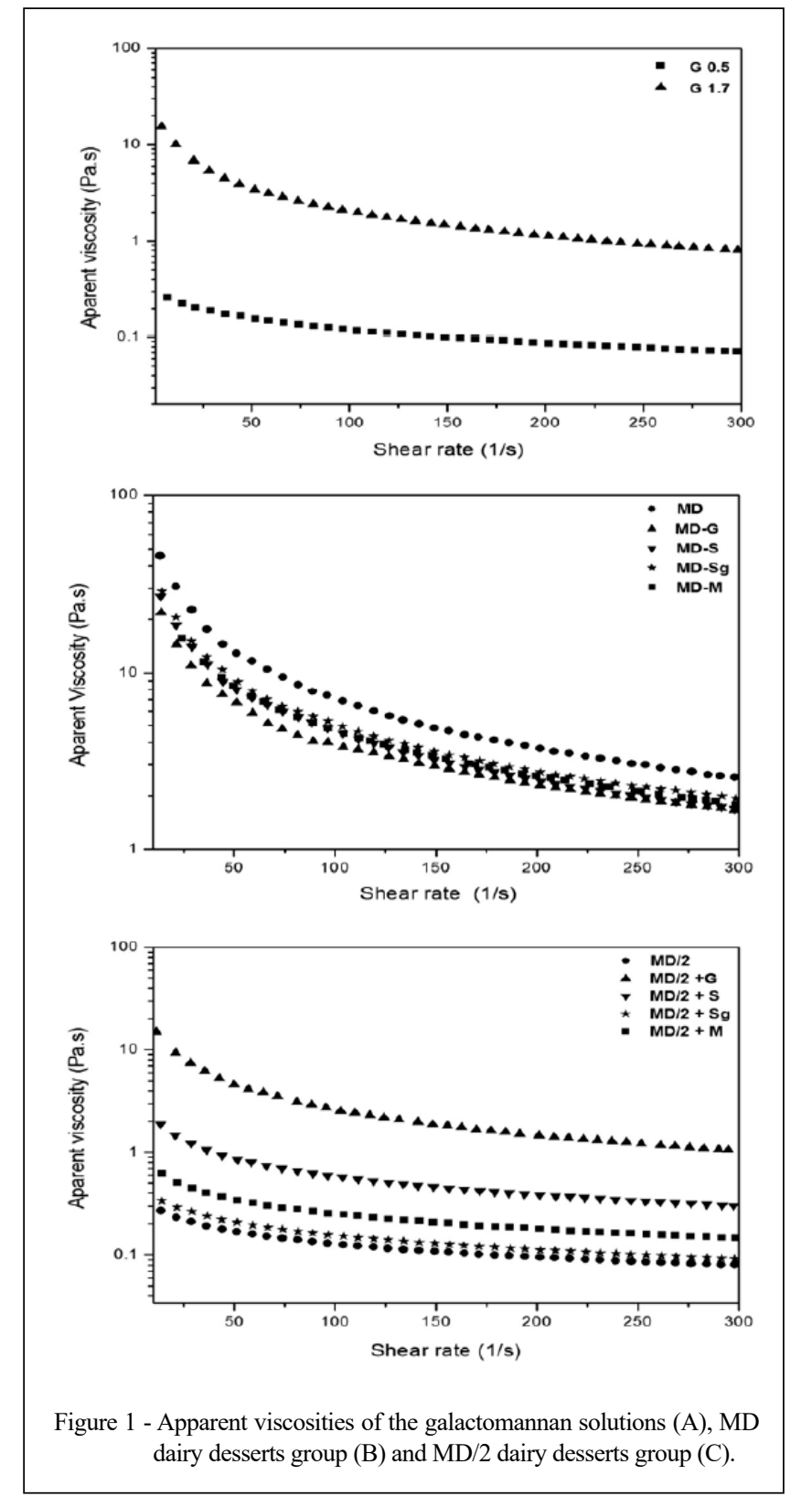

the galactomannan presented a better thickening power when the concentration of the others ingredients were reduced, as in $\mathrm{MD} / 2$ dairy desserts group.

Conversely, galactomannan presented a synergic effect to the other ingredients (starch, milk protein and sucrose). Figure 1B shows a 2.8 -fold decrease in the apparent viscosity of MD dairy desserts group when the concentration of galactomannan from MD-G dairy dessert is decreased (at $10 \mathrm{~s}^{-1}$ ).

The time-dependence of the hysteresis loop areas for $\mathrm{MD}$ and $\mathrm{MD} / 2$ groups and galactomannans solutions are shown in figure 2. Galactomannans solutions (Figure 2A) showed concentrationdependent hysteresis of $65 \mathrm{~Pa}^{-1}(0.5 \%)$ and $820 \mathrm{~Pa}^{-} \mathrm{s}^{-}$ ${ }^{1}(1.7 \%)$. The higher hysteresis loop area, i.e., higher thixotropy, was observed for MD (28.700 Pa.s $\left.\mathrm{s}^{-1}\right)$. This result was attributed to progressive structural break down of the polymers mainly of the starch, since the lower thixotropy was observed for MD-S (4.300 $\left.\mathrm{Pa} . \mathrm{S}^{-1}\right)$. The MD-S hysteresis area was not significant, which suggested that dairy desserts containing less starch present elevated shear resistance and structure 


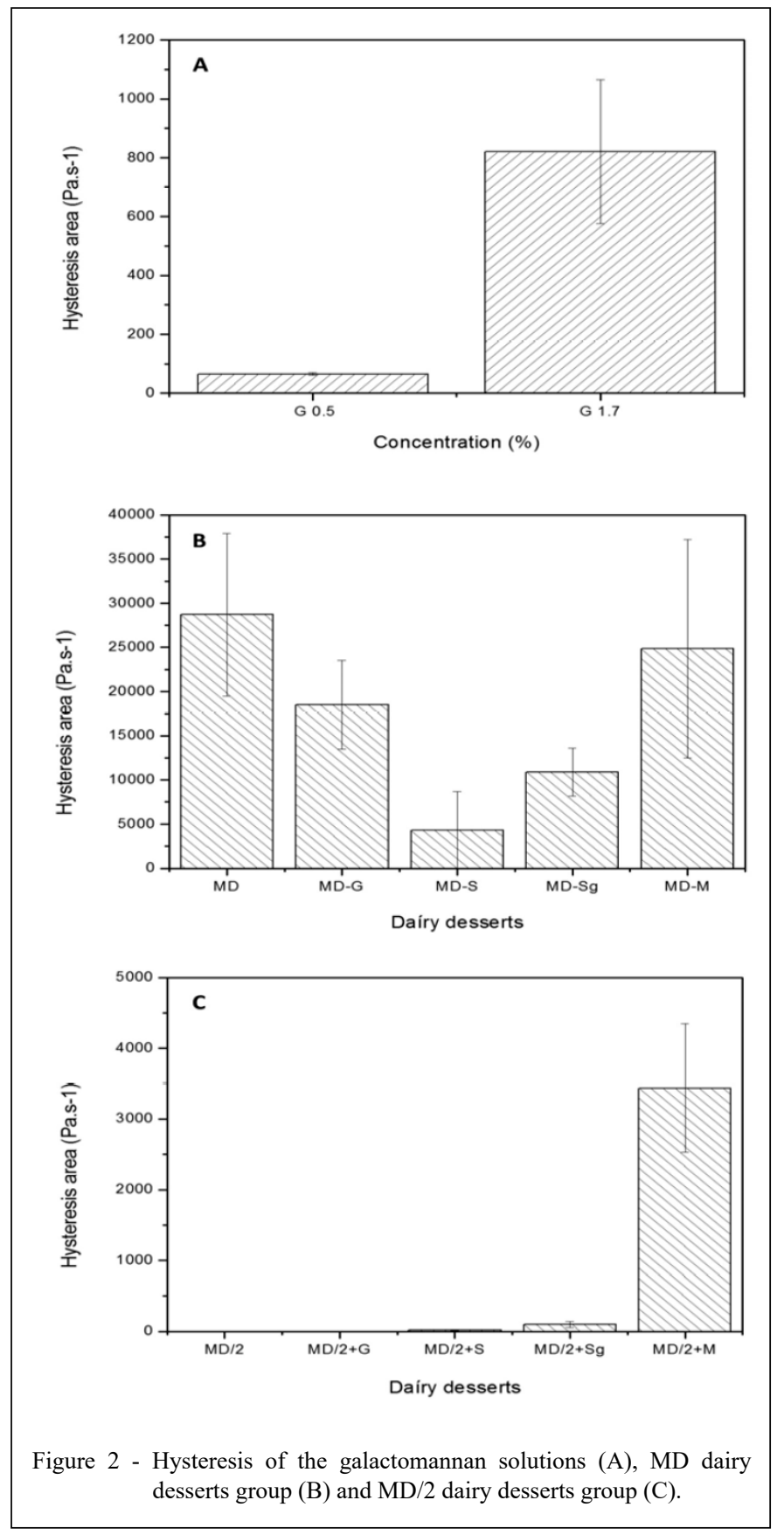

recovery. It is an indicative that high shear rates slightly modify the structure of this system (SCHRAMM, 2006). There were not hysteresis loop area for $\mathrm{MD} / 2$ and $\mathrm{MD} / 2+\mathrm{G}$, however $\mathrm{MD} / 2+\mathrm{M}, \mathrm{MD} / 2+\mathrm{Sg}$ and $\mathrm{MD} / 2+\mathrm{S}$

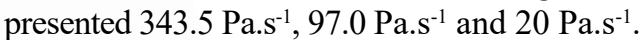

ABU-JDAYIL \& MOHAMEED (2004) analyzed the rheological behavior of a corn starchmilk-sugar paste at different starch concentrations (2,
4 and $6 \% \mathrm{wt}$ ) and a sucrose concentration of $8 \%(\mathrm{wt})$, and they verified that the pastes heated at 85 and 95 ${ }^{\circ} \mathrm{C}$ for 30 min presented the highest viscosities and hysteresis related to the concentration of starch and its gelatinization.

The rheological parameters are shown in table 3 . The flow curves were fitted by the power law model and presented a good fit $\left(\mathrm{R}^{2} \geq 0.93\right)$. Both 
Table 3 - Rheological parameters of the galactomannan solutions and dairy desserts groups by Power Law.

\begin{tabular}{|c|c|c|c|c|c|c|}
\hline \multirow{3}{*}{$\begin{array}{l}\text { Galactomannsolutions } \\
\text { and dairy desserts }\end{array}$} & \multicolumn{6}{|c|}{ 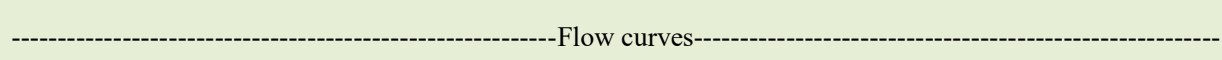 } \\
\hline & \multicolumn{3}{|c|}{ 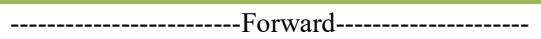 } & \multicolumn{3}{|c|}{ 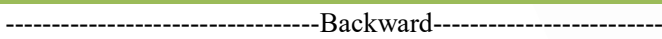 } \\
\hline & $k(\mathrm{~Pa} . \mathrm{s})$ & $n$ & $\mathrm{R}^{2}$ & $k(\mathrm{~Pa} . \mathrm{s})$ & $N$ & $\mathrm{R}^{2}$ \\
\hline $0.5 \%$ & $0.90^{\mathrm{b}} \pm 0.042$ & $0.55^{\mathrm{a}} \pm 0.007$ & 0.99 & $1.14^{\mathrm{b}} \pm 0.184$ & $0.51^{\mathrm{a}} \pm 0.010$ & 0.99 \\
\hline $1.7 \%$ & $76.41^{\mathrm{a}} \pm 2.291$ & $0.20^{\mathrm{b}} \pm 0.009$ & 0.95 & $77.82^{\mathrm{a}} \pm 4.301$ & $0.19^{b} \pm 0.001$ & 0.95 \\
\hline MD & $520.02^{\mathrm{a}} \pm 10.18$ & $0.06^{\mathrm{c}} \pm 0.001$ & 0.93 & $205.40^{b} \pm 11.50$ & $0.22^{\mathrm{c}} \pm 0.007$ & 0.99 \\
\hline MD-G & $165.20^{c} \pm 5.72$ & $0.22^{\mathrm{a}} \pm 0.007$ & 0.94 & $56.16^{\mathrm{a}} \pm 10.28$ & $0.37^{\mathrm{a}} \pm 0.033$ & 0.98 \\
\hline MD-S & $279.75^{\mathrm{d}} \pm 10.11$ & $0.10^{\mathrm{d}} \pm 0.014$ & 0.94 & $217.00^{\mathrm{b}} \pm 5.00$ & $0.15^{b} \pm 0.001$ & 0.96 \\
\hline $\mathrm{MD}-\mathrm{Sg}$ & $288.50^{d} \pm 4.73$ & $0.11^{\mathrm{d}} \pm 0.010$ & 0.98 & $130.65^{\mathrm{c}} \pm 2.89$ & $0.24^{\mathrm{c}} \pm 0.007$ & 0.99 \\
\hline MD-M & $192.70^{b} \pm 3.95$ & $0.18^{\mathrm{b}} \pm 0.007$ & 0.95 & $130.65^{\mathrm{c}} \pm 2.89$ & $0.24^{\mathrm{c}} \pm 0.007$ & 0.99 \\
\hline $\mathrm{MD} / 2$ & $0.89^{c} \pm 0.06$ & $0.57^{\mathrm{a}} \pm 0.007$ & 0.99 & $0.98^{c} \pm 0.007$ & $0.56^{\mathrm{a}} \pm 0.000$ & 0.99 \\
\hline $\mathrm{MD} / 2+\mathrm{G}$ & $34.47^{\mathrm{a}} \pm 0.81$ & $0.28^{\mathrm{e}} \pm 0.001$ & 0.99 & $36.41^{\mathrm{a}} \pm 1.651$ & $0.27^{\mathrm{e}} \pm 0.002$ & 0.99 \\
\hline $\mathrm{MD} / 2+\mathrm{S}$ & $9.03^{\mathrm{b}} \pm 1.50$ & $0.40^{\mathrm{d}} \pm 0.003$ & 0.99 & $7.59^{\mathrm{b}} \pm 0.153$ & $0.44^{\mathrm{d}} \pm 0.001$ & 0.99 \\
\hline $\mathrm{MD} / 2+\mathrm{Sg}$ & $1.27^{\mathrm{c}} \pm 0.032$ & $0.54^{\mathrm{b}} \pm 0.010$ & 0.99 & $1.28^{\mathrm{c}} \pm 0.020$ & $0.54^{\mathrm{c}} \pm 0.007$ & 0.99 \\
\hline $\mathrm{MD} / 2+\mathrm{M}$ & $2.30^{c} \pm 0.165$ & $0.51^{c} \pm 0.007$ & 0.99 & $1.91^{\mathrm{c}} \pm 0.040$ & $0.55^{b} \pm 0.001$ & 0.99 \\
\hline
\end{tabular}

MD: high solid levels; MD/2: half the amount of solids; G: galactomannan; S: corn starch; Sg: sucrose; M: powdered milk; $k$ : consistency index; $n$ : flow behavior index; $\mathrm{R}^{2}$ : linear regression coefficient. Means \pm standard deviation. Different letters in the same line differed from each other by the Tukey test $(\mathrm{P}<0.05)$

galactomannan solutions and dairy desserts displayed pseudoplastic behavior with; however, the higher concentration presented a higher flow behavior index ( $n$ $=0.20 \pm 0.009)$ and consistency index $(k=76.4 \pm 2.291$ $\mathrm{Pa} . \mathrm{s})$, with significative difference $(\mathrm{P}<0.05)$.

Substantial differences $(\mathrm{P}<0.05)$ were observed when the flow behavior index and consistency index of MD $(n=0.06 \pm 0.001 ; k=$ $520.02 \pm 10.18$ Pa.s) were compared to those of MD-G $(n=0.22 \pm 0.007 ; k=165.20 \pm 5.72$ Pa.s $)$ and MD-M $(n=0.18 \pm 0.007 ; k=192.70 \pm 3.95$ Pa.s). The low values recorded for MD-S $(n=0.10$ $\pm 0.014 ; k=279.75 \pm 10.11$ Pa.s $)$ and MD-Sg $(n$ $=0.11 \pm 0.010 ; k=288.50 \pm 4.73$ Pa.s) suggested that galactomannan and milk proteins interact and contributed more effectively than starch and sugar in dairy desserts. Moreover, the dairy desserts MD presented consistency indexes highest than MD/2 group due to high dry solid content.

The same behavior has previously been reported for many hydrocolloid solutions and dairy desserts due to their high molecular weight (STEFFE et al., 1995). Similar results have been obtained by SUDHAKAR et al., (1995) when synergism among corn starch, Amaranthus paniculatus starch and galactomannans, such as guar gum and LBG, was evaluated.
The dairy desserts with half the amount of each ingredient (MD/2) displayed flow curves upward and downward that were well fitted by the power law model $\left(\mathrm{R}^{2}=0.99\right)$, and they showed variations in the flow behavior index and consistency, which were lower than those of the MD group. Thus, the galactomannan concentration affected hysteresis, $n$ and $k$ in these desserts, which may be attributed to less stable bonds in the MD group, leading to a greater structure breakdown triggered by the applied shear rates. Galactomannan caused a 38.7fold increase in the consistency index of $\mathrm{MD} / 2+\mathrm{G}$ $(34.47 \pm 0.81 \mathrm{~Pa} . \mathrm{s})$ compared to that of MD/2 (0.89 \pm 0.06 Pa.s), and starch caused a 10.14-fold increase in the consistency index of $\mathrm{MD}+\mathrm{S}$ compared to that of $\mathrm{MD} / 2$. Thixotropy was not observed in the galactomannan solutions (0.5 and $1.7 \%$ ).

The rheological parameters according to the Casson model are shown in table 4. Significant intensification $(\mathrm{P}<0.05)$ in yield stress was observed for the 0.5 and $1.7 \%$ galactomannan solutions (2.32 \pm 0.110 and $118.2 \pm 4.101 \mathrm{~Pa}$, respectively) as a result of increased hydrocolloid concentration.

The Casson model provided positive values of yield stress $\left(\tau_{0}\right)$ and an $\mathrm{R}^{2} \geq 0.84$ to galactomannan solution $1.7 \%$. In contrast, the Hershel-Bulkley model $\left(\mathrm{R}^{2}>0.97\right)$ provided negative values for yield stress; 
Table 4 - Rheological parameters of the galactomannan solutions and dairy desserts groups by Casson model.

\begin{tabular}{|c|c|c|c|c|c|c|}
\hline \multirow{2}{*}{$\begin{array}{l}\text { Galactomannan solutions } \\
\text { and dairy desserts }\end{array}$} & \multicolumn{3}{|c|}{--------------------------'Forward------------------------ } & \multicolumn{3}{|c|}{ 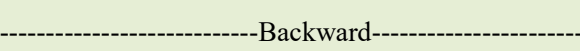 } \\
\hline & $\tau_{0}(\mathrm{~Pa})$ & $\mathrm{k}_{\mathrm{v}}(\mathrm{mPa} . \mathrm{s})$ & $\mathrm{R}^{2}$ & $\tau_{0}(\mathrm{~Pa})$ & $\mathrm{k}_{\mathrm{v}}(\mathrm{mPa} . \mathrm{s})$ & $\mathrm{R}^{2}$ \\
\hline $0.5 \%$ & $2.32^{\mathrm{b}} \pm 0.110$ & $0.03^{b} \pm 0.003$ & 0.97 & $2.69^{b} \pm 0.410$ & $0.03^{\mathrm{b}} \pm 0.001$ & 0.96 \\
\hline $1.7 \%$ & $118.2^{\mathrm{a}} \pm 4.101$ & $0.08^{\mathrm{a}} \pm 0.020$ & 0.84 & $119.5^{\mathrm{a}} \pm 7.350$ & $0.08^{\mathrm{a}} \pm 0.005$ & 0.85 \\
\hline MD & $600.50^{\mathrm{a}} \pm 13.40$ & $0.03^{\mathrm{b}} \pm 0.001$ & 0.90 & $324.4^{\mathrm{b}} \pm 15.130$ & $0.35^{\mathrm{cd}} \pm 0.02$ & 0.85 \\
\hline MD-G & $248.60^{\mathrm{d}} \pm 2.540$ & $0.15^{\mathrm{ab}} \pm 0.010$ & 0.95 & $114.2^{\mathrm{a}} \pm 14.200$ & $0.47^{\mathrm{a}} \pm 0.06$ & 0.88 \\
\hline MD-S & $355.25^{\mathrm{c}} \pm 5.580$ & $0.05^{\mathrm{ab}} \pm 0.010$ & 0.87 & $297.4^{b} \pm 6.290$ & $0.11^{\mathrm{b}} \pm 0.01$ & 0.84 \\
\hline $\mathrm{MD}-\mathrm{Sg}$ & $376.40^{\mathrm{b}} \pm 2.050$ & $0.08^{\mathrm{ab}} \pm 0.140$ & 0.95 & $194.9^{c} \pm 4.240$ & $0.37^{\mathfrak{c}} \pm 0.01$ & 0.94 \\
\hline MD-M & $258.60^{\mathrm{d}} \pm 0.220$ & $0.21^{\mathrm{a}} \pm 0.020$ & 0.93 & $218.3^{\mathrm{c}} \pm 7.140$ & $0.27^{\mathrm{d}} \pm 0.03$ & 0.91 \\
\hline $\mathrm{MD} / 2$ & $2.31^{\mathrm{c}} \pm 0.140$ & $0.04^{c} \pm 0.001$ & 0.94 & $2.41^{\mathrm{c}} \pm 0.010$ & $0.04^{c} \pm 0.010$ & 0.97 \\
\hline $\mathrm{MD} / 2+\mathrm{G}$ & $62.41^{\mathrm{a}} \pm 1.603$ & $0.38^{\mathrm{a}} \pm 0.020$ & 0.99 & $62.53^{\mathrm{a}} \pm 2.960$ & $0.10^{b} \pm 0.010$ & 0.99 \\
\hline $\mathrm{MD} / 2+\mathrm{S}$ & $19.99^{\mathrm{b}} \pm 2.560$ & $0.09^{\mathrm{b}} \pm 0.010$ & 0.99 & $16.88^{\mathrm{b}} \pm 0.010$ & $0.10^{\mathrm{b}} \pm 0.001$ & 0.99 \\
\hline $\mathrm{MD} / 2+\mathrm{Sg}$ & $3.26^{\mathrm{c}} \pm 0.070$ & $0.04^{c} \pm 0.001$ & 0.93 & $3.07^{c} \pm 0.040$ & $0.04^{c} \pm 0.002$ & 0.93 \\
\hline $\mathrm{MD} / 2+\mathrm{M}$ & $5.84^{\mathrm{c}} \pm 0.401$ & $0.06^{\mathrm{c}} \pm 0.007$ & 0.98 & $4.70^{c} \pm 0.100$ & $0.07^{\mathrm{a}} \pm 0.001$ & 0.97 \\
\hline
\end{tabular}

MD: high solid levels; MD/2: half the amount of solids; G: galactomannan; S: corn starch; Sg: sucrose; M: powdered milk; $\tau_{0}$ : initial stress; Kv: Casson plastic viscosity; R: linear regression coefficient. Means \pm standard deviation. Different letters in the same line differed from each other by the Tukey test $(\mathrm{P}<0.05)$.

thus, it was disregarded. The presence of yield stress in certain materials indicated a cross-linked or other interactive structure that must be broken down before flow can occur at an appreciable shear rate (TARREGA \& COSTELL, 2006). The MD dairy desserts showed the yield stress $(600.5 \pm 13.40 \mathrm{~Pa})$ significatively highest $(\mathrm{P}<0.05)$ than MD-G $(248.6 \pm 2.540 \mathrm{~Pa})$, indicating that the decrease in galactomannan concentration reduced the flow resistance. Starch possesses similar properties, and the MD-S dairy dessert presented lower yield stress (355.25 $\pm 5.580 \mathrm{~Pa}$ ) when compared to the MD sample.

\section{Dynamic rheology}

The frequency effects in the storage modulus ( $\left.G^{\prime}\right)$ and loss modulus ( $\left.G^{\prime \prime}\right)$ of the galactomannan solutions as well as the $\mathrm{MD}$ and $\mathrm{MD} / 2$ dairy dessert groups are shown in figure 3 . Results were frequency-dependent, which is widely observed in viscoelastic solutions.

The mechanical spectrum of the $1.7 \%$ galactomannan solution (figure 3a) was characteristic of macromolecular solutions, presenting $G^{\prime}<G^{\prime}$ ' at low frequencies and a cross-over at higher frequencies. In true gels, this type of dependence is reduced. The $0.5 \%$ galactomannan solution showed frequency-dependence with no cross-over.

The mechanical spectrum of the MD dairy dessert group (figure 3b) displayed a storage modulus $\left(G^{\prime}\right)$ that was greater than the loss modulus (G'), exhibiting characteristic gel behavior in all examined frequency ranges. Nonetheless, the difference between the gel moduli in the dairy desserts characterized these systems as weak gels. The MD-Sg storage modulus $\left(G^{\prime}\right)$ was 9.0 times greater than that of the MD sample, which may be related to the diminishing sucrose that modified the gel structure by inducing a cross-linked formation. In contrast, the decrease of galactomannan (MD-G) promoted gel characteristics, with an elastic modulus that was less dependent on frequency. Similar behavior was observed with the less frequency-dependent gel system obtained by galactomannan addition in $\mathrm{MD} / 2$ (figure $3 \mathrm{c}$ ). The $\mathrm{MD} / 2+\mathrm{M}$ and $\mathrm{MD} / 2+\mathrm{Sg}$ dairy desserts presented the highest frequency-dependent moduli.

The mechanical spectra as a function of temperature were also investigated for the galactomannan solutions as well as the $\mathrm{MD}$ and $\mathrm{MD} / 2$ dairy dessert groups. The storage moduli (G') were smaller than the loss moduli (G”) for both galactomannan solutions $(0.5$ and $1.7 \%)$ at $10{ }^{\circ} \mathrm{C}$, and the absolute values of the moduli were decreased by heating (figures $4 \mathrm{a}$ and $4 \mathrm{~b}$ ). Galactomannans behave as typical neutral polysaccharides because they are rich in hydroxyl groups, which are involved in inter-chain H-bonds, contributing to high $G^{\prime}$ values. However, some of these H-bonds are disrupted at higher temperatures, which promotes a decrease in the absolute values of G'. ALBUQUERQUE et al., (2014) observed similar

Ciência Rural, v.50, n.6, 2020. 


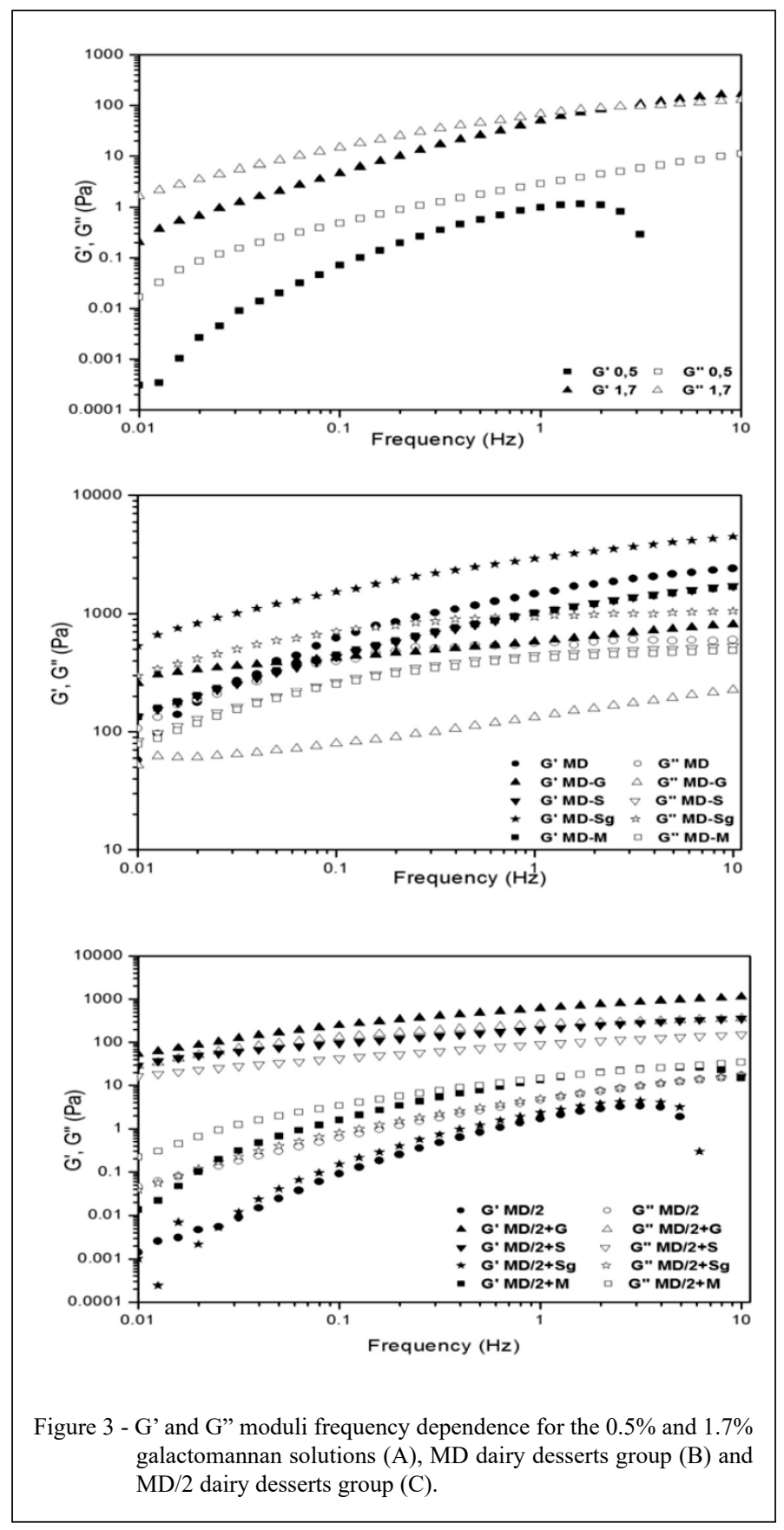

results when evaluating the rheological behavior of Cassia grandis seed galactomannan solutions at different concentrations. In contrast, all the $\mathrm{MD}$ and $\mathrm{MD} / 2$ dairy dessert samples presented solid-like behaviors $\left(\mathrm{G}^{\prime}>\mathrm{G}^{\prime}\right)$ over all analyzed temperature ranges $\left(5\right.$ at $\left.80^{\circ} \mathrm{C}\right)$ with lower $\mathrm{G}^{\prime}$ values in the 5 to $50{ }^{\circ} \mathrm{C}$ temperature range, which was similar to the behavior of the galactomannan solution, and higher $\mathrm{G}^{\prime}$ values at 50 to $80{ }^{\circ} \mathrm{C}$ (Figures
$4 \mathrm{c}$ and $4 \mathrm{~d})$. Temperatures above $50{ }^{\circ} \mathrm{C}$ induced changes in the chemical structure of polymers in the desserts (proteins, starch and galactomannan), which can promote chain aggregations that contribute to increased $G^{\prime}$ and G" values. Similarly, C. pulcherrima galactomannans induced a synergic effect when the MD-G sample showed G' and G" values that were significantly lower than those of the MD sample (Figure 4c). In fact, 

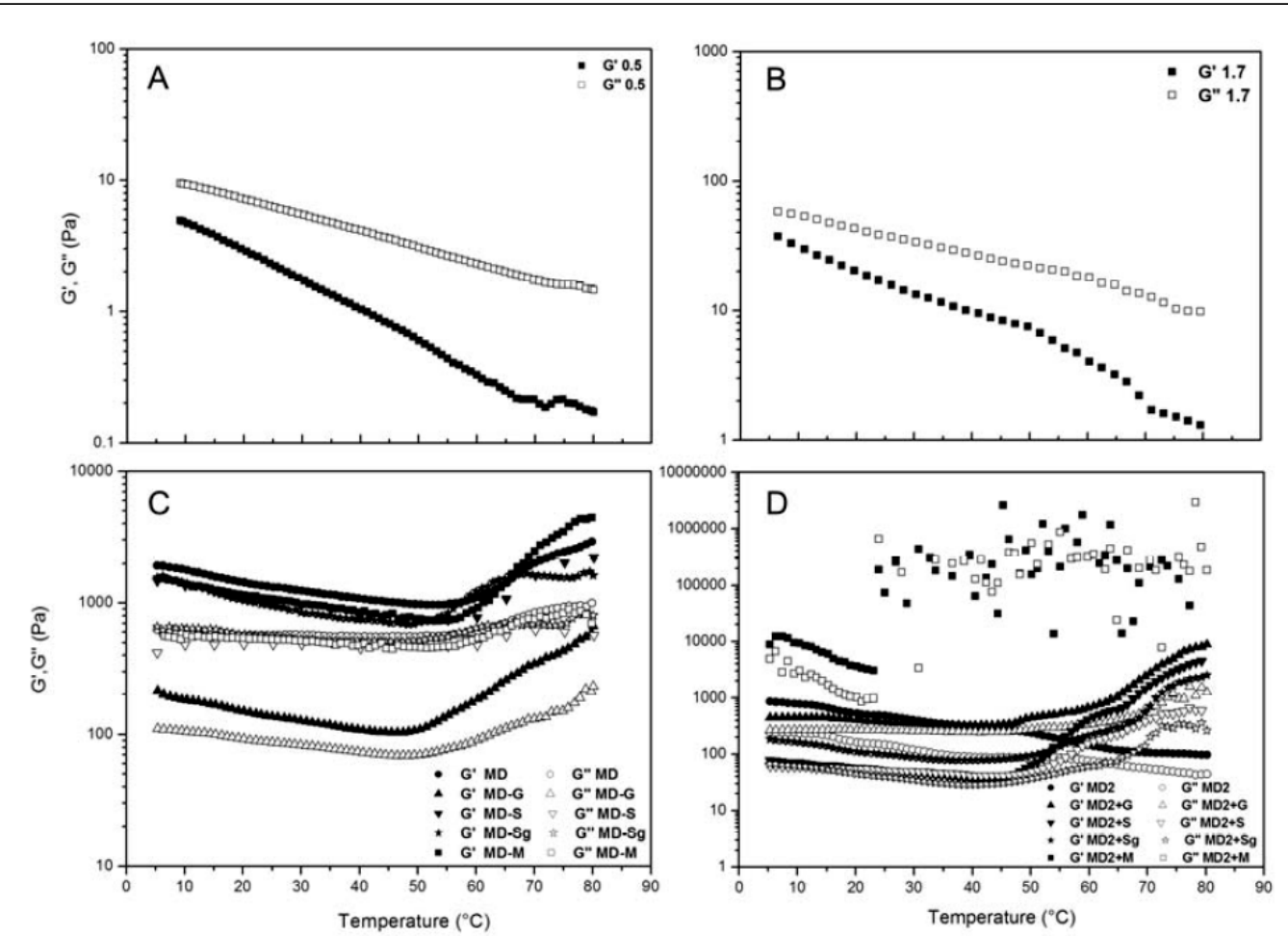

Figure 4 - The mechanical spectra of the $0.5 \%(\mathrm{~A})$ and $1.7 \%(\mathrm{~B})$ galactomannan solutions, MD dairy desserts group (C) and $\mathrm{MD} / 2$ dairy desserts group (D) as a function of temperature.

modifications in the intermolecular network can be induced when formulations, and especially food products, are submitted to temperature cycles, thus improving industrial applications. A synergistic effect in the Mimosa scabrella galactomannan and milk protein system was also observed by PERISSUTTI et al., (2002).MD.

The MD/2 dairy dessert group showed decreasing moduli values (G' and $\mathrm{G}^{\prime}$ ) until $50^{\circ} \mathrm{C}$ (figure $4 \mathrm{D}$ ); however, $\mathrm{MD} / 2$ presented continuous reduction until $80^{\circ} \mathrm{C}$. At $50{ }^{\circ} \mathrm{C}$, the $\mathrm{MD} / 2+\mathrm{S}, \mathrm{MD} / 2+\mathrm{Sg}$ and $\mathrm{MD} / 2+\mathrm{G}$ moduli increased, and the addition of galactomannan to $\mathrm{MD} / 2$ promoted the highest G' and G' values, thereby suggesting that galactomannans contribute to polymeric intermolecular interactions in the $50-80{ }^{\circ} \mathrm{C}$ temperature range. The $\mathrm{MD} / 2+\mathrm{M}$ dessert had incongruent points, which were most likely due to molecular structure disruption and gel character loss (VRIESMANN et al., 2009).

\section{CONCLUSION}

Caesalpinia pulcherrima seeds is source of galactomannan with physicochemical characteristics of commercial importance, presenting property thickener, pseudoplastic behavior and hysteresis that ranged with the concentration in aqueous solution and synergism when in presence of starch, milk protein and sucrose in dairy desserts. The viscoelasctic behavior of galactomannans concentrated aqueous solution were more affected by frequency and temperature. Effect similar was observed with dairy desserts in presence of milk. Therefore, the galactomannan from Caesalpinia pulcherrima constituted a versatile and alternative thickener agent for to be used in foods of dairy bases.

\section{ACKNOWLEDGMENTS}

The authors are grateful of to the Graduate Program of Northeastern Network Biotechnology (RENORBIO) for the institutional support for this research.

\section{DECLARATION OF CONFLICT OF INTERESTS \\ The authors declare no conflict of interest. The founding sponsors had no role in the design of the study; in the}


collection, analyses, or interpretation of data; in the writing of the manuscript, and in the decision to publish the results.

\section{AUTHORS' CONTRIBUTIONS}

SRMA designed the study and interpreted the results AMCO helped to collect test data; MLHA helped to analyze the rheology results; FDS collected test data and drafted the manuscript; VAO and RCMP characterized the galactomannan; ACOMM provided the galactomannan from Caesalpinia pulcherrima; FJB designed the study and RAM drafted the manuscript and made English version.

\section{REFERENCES}

ABU-JDAYIL, B.; MOHAMEED, H. A. Time-dependent flow properties of starch?milk?sugar pastes. Eur. Food Res. Technol. v.218, p.123-127, 2004. Available from: <https://link.springer. com/article/10.1007/s00217-003-0829-6>. Accessed: Jun. 24, 2019. doi: 10.1007/s00217-003-0829-6.

ALbUQUerque, P. B. S., et al. Characterization and rheological study of the galactomannan extracted from seeds of Cassia grandis. Carbohydr. Polym. v.104, p.127-34, 2014. Available from: <https://www.sciencedirect.com/science/ article/pii/S0144861714000125>. Accessed: Jun. 24, 2019. doi: 10.1016/j.carbpol.2014.01.010.

ANDRADE, C. T., et al. Solution properties of the galactomannans extracted from the seeds of Caesalpinia pulcherrima and Cassia ja 6 anica : comparison with locust bean gum. Int $\mathbf{J}$ Biol Macromol. v.26, p.181-185, 1999. Available from: <https:// www.sciencedirect.com/science/article/pii/S0141813099000756>. Accessed: Jun. 24, 2019. doi. 10.1016/S0141-8130(99)00075-6.

ANTÔNIO, M., et al. Curdlan: an important microbial hydrocolloid. Semina: Ciências Agrárias. p.379-384, 2003. Available from: <http://www.uel.br/portal/index. php?pagina $=404 \&$ urlProcurada $=$ www.uel.br $/$ proppg $/$ portal $/$ pages/arquivos/pesquisa/semina/pdf/semina_24_2_19_23.pdf $>$. Accessed: Jun. 24, 2019.

AZERO, E. G.; ANDRADE, C. T. Testing procedures for galactomannan purification. Polym. Test. v.21, p.551-556, 2002. Available from: <https://www.sciencedirect.com/science/article/ pii/S0142941801001234>. Accessed: Jun. 24, 2019. doi: 10.1016 S0142-9418(01)00123-4.

BAETHGEN, W. E., ALLEY, M. M. A manual colorimetric procedure for measuring ammonium nitrogen in soil and plant Kjeldahl digests. Commun. Soil Sci. Plant Anal. v.20, p.961969, 1989. Available from: <https://www.tandfonline.com/doi/ abs/10.1080/00103628909368129>. Accessed: Jun. 24, 2019. doi: $10.1080 / 00103628909368129$.

BENTO, J. F., et al. Diverse patterns of cell wall mannan/ galactomannan occurrence in seeds of the Leguminosae. Carbohydr. Polym. v.92, p.192-9, 2013. Available from: $<$ https:// www.sciencedirect.com/science/article/pii/S0144861712009058>. Accessed: Jun. 24, 2019. doi: 10.1016/j.carbpol.2012.08.113.

BURITI, F. C. a., et al. Characterisation of partially hydrolysed galactomannan from Caesalpinia pulcherrima seeds as a potential dietary fibre. Food Hydrocoll. v. 5, p.512-521, 2014. Available from: <https://www.sciencedirect.com/science/
article/pii/S0268005X13002178>. Accessed: Jun. 24, 2019. doi: 10.1016/j.foodhyd.2013.07.015.

CERQUEIRA, M. A. et al. Extraction, purification and characterization of galactomannans from non-traditional sources. Carbohydr. Polym. v.75, p.408-414, 2009. Available from: <https://www. sciencedirect.com/science/article/pii/S0144861708003482>. Accessed: Jun. 24, 2019. doi: 10.1016/j.carbpol.2008.07.036.

CEVOLI, C., et al. Rheological characterisation of selected food hydrocolloids by traditional and simplified techniques. Food Hydrocoll. v.33, p.142-150, 2013. Available from: <https://www. sciencedirect.com/science/article/pii/S0268005X13000726>. Accessed: Jun. 24, 2019. doi: 10.1016/j.foodhyd.2013.02.022.

DEA, I. C. M., et al. Carbohydrate Research, v.147, p.275-294, 1986.

VÉLEZ-RUIZ, F. J., et al., Rheology of dairy custard model systems: Influence of milk -fat and hydrocolloid type. Eur. Food Res. Technol. v.221, p.342-347, 2005. Available from: <https:// link.springer.com/article/10.1007/s00217-005-1174-8>. Accessed: Jun. 24, 2019. doi: 10.1007/s00217-005-1174-8.

FINCH, C. A. Book Review: Hydrocolloid applicationsgum technology in the food and other industries. Blackie Academic \& Professional, London. 1998. Available from: $<$ https://onlinelibrary.wiley.com/doi/abs/10.1002/(SICI)10970126(199804)45:4\%3C428::AID-PI962\%3E3.0.CO;2-N>. Accessed: Jun. 24, 2019. doi:10.1002/(SICI)10970126(199804)45:4<428::AID-PI962>3.0.CO;2-N.

KAPOOR, V. P., DIVISIONS, P. Seed Galactomannans : An Overview 2. 2005. LETHUAUT, L., et al. Sweetness-texture interactions in model dairy desserts: effect of sucrose concentration and the carrageenan type. Int. Dairy J. v.13, p.631-641, 2003. Available from: <https://www.sciencedirect.com/science/article/ pii/S0958694603001067>. Accessed: Jun. 24, 2019. doi: 10.1016/ S0958-6946(03)00106-7.

MA, J., et al. Flow behavior, thixotropy and dynamical viscoelasticity of sodium alginate aqueous solutions. Food Hydrocoll. v.38, p.119-128, 2014. Available from: <https://www. sciencedirect.com/science/article/pii/S0268005X13003779>. Accessed: Jun. 24, 2019. doi: 10.1016/j.foodhyd.2013.11.016.

MIKKONEN, K. S., et al. Effect of Polysaccharide Structure on Mechanical and Thermal Properties of Galactomannan-Based Films, p.3198-3205, 2007. Available from: <https://pubs.acs. org/doi/abs/10.1021/bm700538c >. Accessed: Jun. 24, 2019. doi: $10.1021 / \mathrm{bm} 700538 \mathrm{c}$.

OGY, I., et al. OI Otll.: Water-soluble galactomannans from seeds of Mimosaceae spp . v.68, p.55-62, 1999. Available from: <https:// www.sciencedirect.com/science/article/pii/S0960852498000789>. Accessed: Jun. 24, 2019. doi: 10.1016/S0960-8524(98)00078-9.

PERISSUTTI, G., et al. Interaction between the galactomannan from Mimosa scabrella and milk proteins. Food Hydrocoll. v.16, p.403-417, 2002. Available from: <https:/www.sciencedirect. com/science/article/pii/S0268005X01001138>. Accessed: Jun. 24, 2019. doi: 10.1016/S0268-005X(01)00113-8.

PRAJAPATI, V. D., et al. Galactomannan: a versatile biodegradable seed polysaccharide. Int. J. Biol. Macromol. v.60, p.83-92, 2013. Available from: <https://www.sciencedirect.com/science/

Ciência Rural, v.50, n.6, 2020. 
article/pii/S0141813013002808>. Accessed: Jun. 24, 2019. doi: 10.1016/j.ijbiomac.2013.05.017.

SCHRAMM, G. Reologia e reometria: fundamentos teóricos e práticos. Artliber Ed, São Paulo. 2006.

STEFFE, J. F., et al. RHEOLOGICAL METHODS. IN.: Sudhakar, V., Singhal, R.S., Kulkarni, P.R. Effect of sucrose on starch-hydrocolloid interactions. Food Chem. v.52, p.281-284, 1995. Available from: <https://www.sciencedirect.com/science/ article/pii/0308814695928244>. Accessed: Jun. 24, 2019. doi: 10.1016/0308-8146(95)92824-4.

TÁRREGA, A., et al. Flow behaviour of semi-solid dairy desserts. Effect of temperature. Int. Dairy J. v.14, p.345-353, 2004. Available from: $<$ https://www.sciencedirect.com/science/ article/pii/S0958694603002887>. Accessed: Jun. 24, 2019. doi: 10.1016/j.idairyj.2003.12.004.

TARREGA, A., COSTELL, E. Effect of composition on the rheological behaviour and sensory properties of semisolid dairy dessert. Food Hydrocoll. v.20, p.914-922, 2006. Available from: <https://www.sciencedirect.com/science/ article/pii/S0268005X0500202X>. Accessed: Jun. 24, 2019. doi: 10.1016/j.foodhyd.2005.09.006.

TÁRREGA, A., et al., Rheological characterization of semisolid dairy desserts. Effect of temperature. Part of this paper was presented as a poster at "The Twelfth Gums and Stabilisers for the Food Industry Conference", Wrexham, June 24-27, 2003. Food Hydrocoll. v.19, p.133-139, 2005. Available from: $<$ https://www. sciencedirect.com/science/article/pii/S0268005X0400061X>. Accessed: Jun. 24, 2019. doi: 10.1016/j.foodhyd.2004.04.022.

VRIESMANN, L. C., et al. Chemical and rheological properties of a starch-rich fraction from the pulp of the fruit cupuassu
(Theobroma grandiflorum). Mater. Sci. Eng. v.C29, p.651-656, 2009. Available from: <https://www.sciencedirect.com/science/ article/pii/S0928493108003810>. Accessed: Jun. 24, 2019. doi: 10.1016/j.msec.2008.12.011.

WISCHMANN, B., et al. Food product models developed to evaluate starch as a food ingredient. Nahrung, v.46, p.167-73, 2002. Available from: $<$ https://scholarworks.aub.edu.lb/bitstream/ handle/10938/21049/st-6579.pdf?sequence $=1>$. Accessed: Jun. 24, 2019. doi: 10.1002/1521-3803(20020501)46:3<167::AIDFOOD167>3.0.CO;2-D.

WU, Y., et al. An investigation of four commercial galactomannans on their emulsion and rheological properties. Food Res. Int. v.42, p.1141-1146, 2009. Available from: <https://www.sciencedirect. com/science/article/pii/S0963996909001677>. Accessed: Jun. 24, 2019. doi: 10.1016/j.foodres.2009.05.015.

WU, Y., et al., The rheological properties of tara gum (Caesalpinia spinosa). Food Chem. v.168, p.366-71, 2015. Available from: <https://www.sciencedirect.com/science/ article/pii/S0308814614011315>. Accessed: Jun. 24, 2019. doi: 10.1016/j.foodchem.2014.07.083.

XU, R. B., et al., Chemical composition and antioxidant activities of three polysaccharide fractions from pine cones. Int. J. Mol. Sci. v.13, p.14262-77, 2012. Available from: $<$ https://www.mdpi. com/1422-0067/13/11/14262>. Accessed: Jun. 24, 2019. doi: $10.3390 /$ ijms 131114262 .

YANG, L.; ZHANG, L. M. Chemical structural and chain conformational characterization of some bioactive polysaccharides isolated from natural sources. Carbohydr. Polym. v.76, p.349361, 2009. Available from: <https://www.sciencedirect.com/ science/article/pii/S0144861708005754>. Accessed: Jun. 24, 2019. doi: 10.1016/j.carbpol.2008.12.015. 